\title{
Dynamic Secondary Borehole-Sealing Method for Gas Drainage Boreholes along the Coal Seam
}

\author{
Wei Qin (1) and Jialin Xu $(\mathbb{B}$ \\ State Key Laboratory of Coal Resources and Mine Safety, School of Mines, China University of Mining and Technology, Xuzhou, \\ Jiangsu Province 221116, China \\ Correspondence should be addressed to Jialin Xu; xujlcumt@163.com
}

Received 28 May 2018; Accepted 24 June 2018; Published 17 July 2018

Academic Editor: Wen Wang

Copyright (C) 2018 Wei Qin and Jialin Xu. This is an open access article distributed under the Creative Commons Attribution License, which permits unrestricted use, distribution, and reproduction in any medium, provided the original work is properly cited.

\begin{abstract}
Under the influence of advanced abutment pressure, the tightness of a borehole is destroyed, so secondary borehole sealing is needed; however, the opportune time for a secondary borehole sealing is unclear. In addition, current borehole-sealing devices do not have a secondary borehole-sealing functionality. In this paper, an opportunity election model of secondary borehole sealing was established, and a dynamic secondary borehole-sealing device was developed. In working face 3908 of the Kaiyuan Coal Mine, an in situ dynamic secondary borehole-sealing test was conducted. The test results show that the tightness of the boreholes sealed with high-water-expansion slurry is obviously better than that of the boreholes sealed with cement mortar and polyurethane. When a borehole is destroyed by the peak of the advanced abutment pressure, the secondary borehole-sealing measures can significantly improve borehole suction pressure, gas concentration, and gas drainage amount in the advanced abutment pressure loading stage.
\end{abstract}

\section{Introduction}

Coalbed methane is a kind of nonconventional natural gas associated with coal and adsorbed in coal seams, and countries all over the world exploit and utilize it as a substitutive strategic new energy source $[1,2]$. The increase in coal seam mining depth in China means an increase in the pressure gradient of coalbed methane, and coalbed methane emission from mining increases accordingly [3, 4]. In China, gas drainage from a coal seam is usually performed through boreholes along the coal seam. Nevertheless, coal seams in China are universally characterized by low permeability, so the gas flow rate from boreholes along the coal seam is very low. In addition, with the continuous enlargement of roadway deformation, the tightness of the boreholes along the coal seam weakens, and fresh air enters the drainage pipeline via the drainage boreholes, so the gas concentration from the mining seam decreases while the suction pressure loss increases, which greatly increases the utilization cost of gas from a mining seam [5]. Therefore, how to raise the gas flow rate and concentration from a mining seam and reduce the suction pressure loss in the pipeline have become key aspects that need to be urgently addressed.

When coal is extracted, the coal masses experience an in situ stress stage, an advanced abutment pressure loading stage, and an unloading stage after the peak of the advanced abutment pressure vertically in turn (Figure 1) [6]. At the unloading stage after the peak of the advanced abutment pressure, the permeability of coal masses increases gradually; in particular, at the late unloading stage, coal masses near the coal wall are destroyed owing to the decrease in horizontal stress, and the permeability of coal masses might increase by 2-3 orders of magnitude, exhibiting pressure relief and permeability increase, so the gas flow rates from boreholes in this range become an order of magnitude greater than those from boreholes in the in situ stress area. However, at the unloading stage after the peak of the advanced abutment pressure, the permeability of the coal mass increases, while the tightness of the borehole is destroyed, so a large amount of fresh air enters the borehole, resulting in a sharp decrease in both the suction pressure and gas drainage concentration in the borehole, and the advantage of high permeability in 


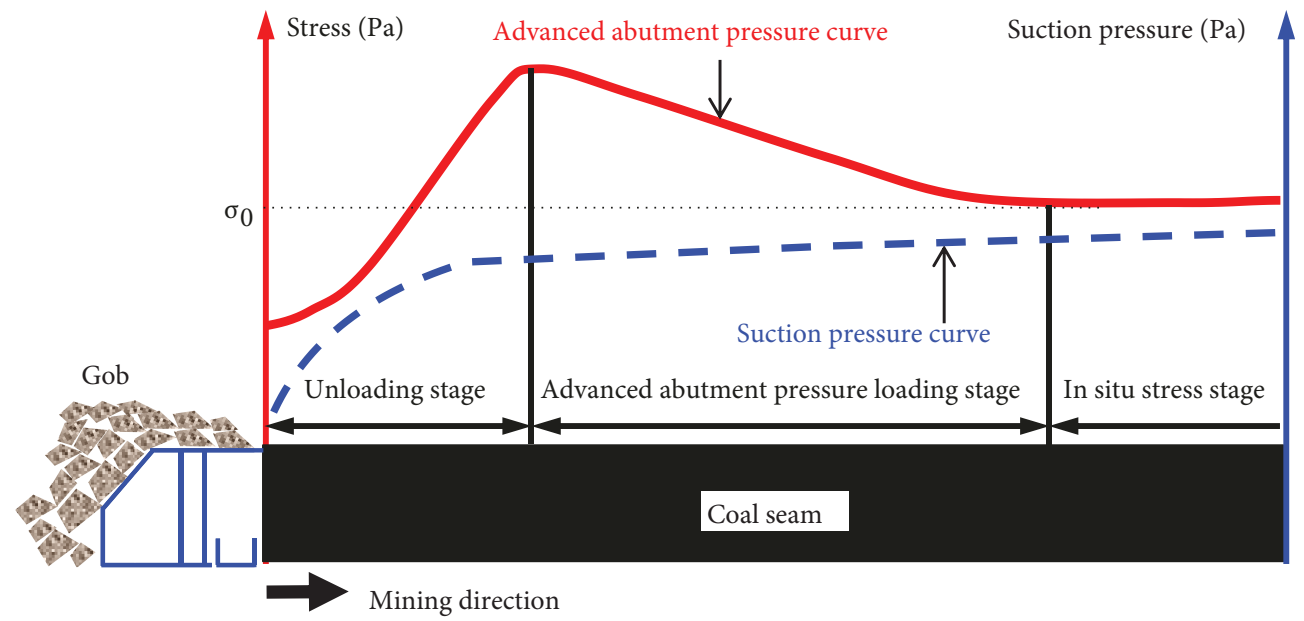

Figure 1: Variation of stress and suction pressure in front of the working face.

the advanced abutment pressure loading stage could not be effectively exploited.

The damaged boreholes should be sealed again. Selecting the right timing is the key to improve the tightness of the borehole. Nevertheless, the opportune time for secondary borehole sealing is unclear. In addition, with existing borehole-sealing devices, one cannot take remedial measures after the borehole tightness is destroyed by the advanced abutment pressure, and the favourable opportunity for gas drainage at the advanced pressure unloading stage is missed. In this paper, an opportunity election model of secondary borehole sealing was established, and the critical gas concentration for secondary borehole sealing was obtained finally through calculation. In addition, a dynamic secondary borehole-sealing device was also developed in this paper. The secondary borehole-sealing test was conducted by using the high-water-expansion borehole-sealing material after the borehole tightness was destroyed, and gas drainage after secondary borehole sealing was investigated.

\section{Opportunity Election Model of Secondary Borehole-Sealing}

It is crucial to choose the correct timing for secondary borehole sealing. In order to obtain a reasonable timing, an opportunity election model of secondary borehole sealing was established in this paper.

2.1. Establishment of the Model. When coal is extracted, the working face advances constantly and the coal masses in front of the working face experience an elastic deformation stage and a plastic deformation stage after the peak of the advanced abutment pressure vertically, in turn, which correspond to the elastic deformation area and the plastic deformation area, respectively. To facilitate the development of the model, a generalized process was devised by assuming that $n$ groups of boreholes were laid in the elastic deformation area and only 1 group of boreholes were laid in the plastic deformation area at a working face in the Kaiyuan
Coal Mine (Figure 2). The processes for both are presented as follows:

(1) Gas flow rate from boreholes in the elastic deformation area: a field test was conducted for the gas flow rate from boreholes in the elastic deformation area of the intake airway for the 3710 working face, and the curves of the gas flow rate from boreholes versus suction pressure in the elastic deformation area were obtained, as shown in Figure 3(a). As can be discerned from Figure 3(a), the correlation between the gas flow rate from each borehole and the suction pressure is not evident in the elastic deformation area. The gas flow rate from boreholes attenuated with drainage time according to an exponential law, so the gas flow rate $q_{t i}$ (in $\mathrm{m}^{3} / \mathrm{min}$ ) from the $i$ th group of drainage boreholes into the main pipeline can be expressed as follows:

$$
q_{t i}=k_{1 i} \exp \left(k_{2 i} t\right),
$$

where $k_{1 i}$ is the initial gas flow rate from the $i$ th group of drainage boreholes in $\mathrm{m}^{3} / \mathrm{min}, k_{2 i}$ is the attenuation coefficient of the gas flow rate from the $i$ th group of drainage boreholes, and $t$ is the drainage time in days.

(2) Gas flow rate from boreholes in the plastic deformation area: in the plastic deformation area, the permeability of the coal mass increased rapidly by 2-3 orders of magnitude, exhibiting a "pressure relief and permeability increase" effect; the gas flow rate from boreholes in this area was extremely sensitive to the suction pressure. The test results showed that the gas flow rate $q_{s}$ (in $\mathrm{m}^{3} / \mathrm{min}$ ) from boreholes increased with the suction pressure according to a logarithmic function (Figure 3(b)), so

$$
q_{s}=k_{3} \ln \left(p_{c}\right)+k_{4},
$$

where $p_{c}$ is the suction pressure in grouped boreholes in the plastic deformation area in pascals, and $k_{3}$ and $k_{4}$ are fitting coefficients. 


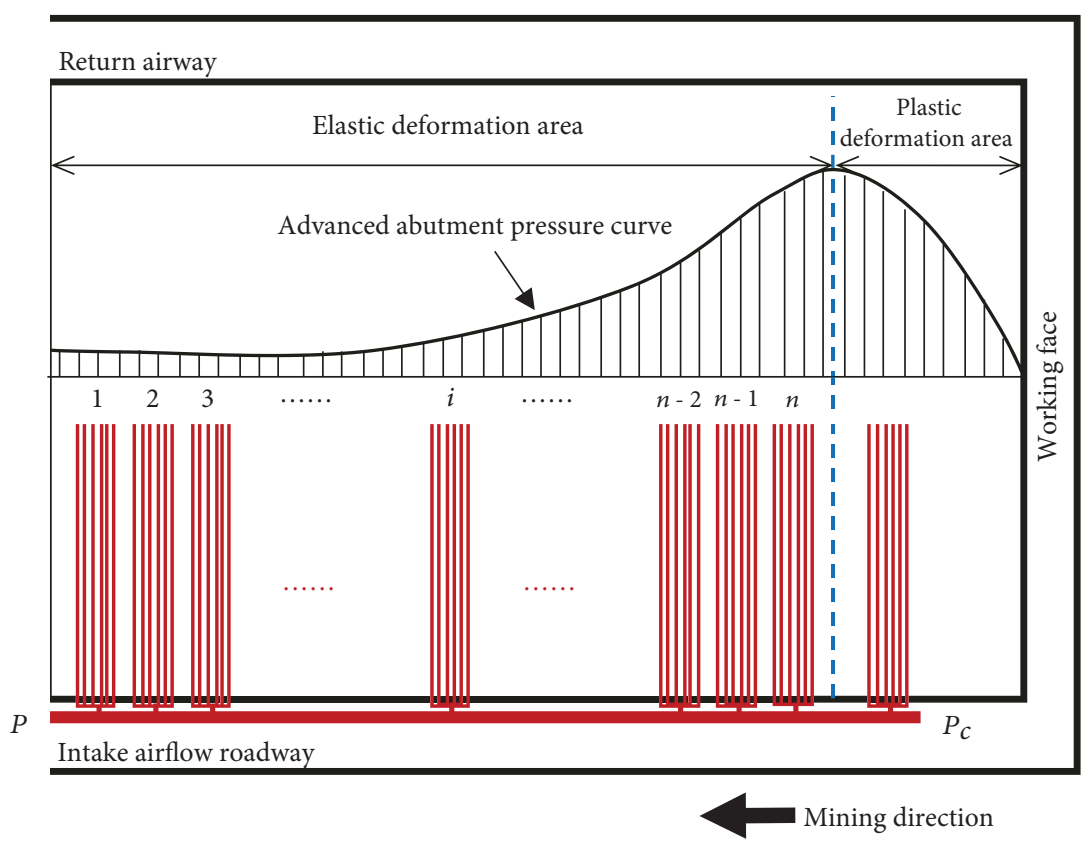

FIgURE 2: Schematic diagram of gas drainage characteristic zoning and distribution of drainage boreholes at the mining seam.

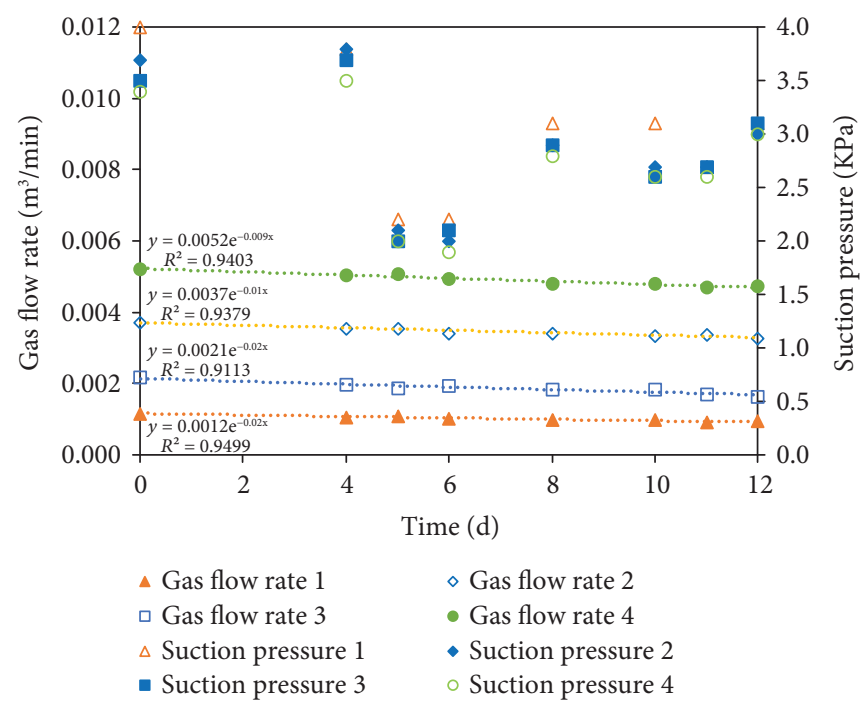

(a)

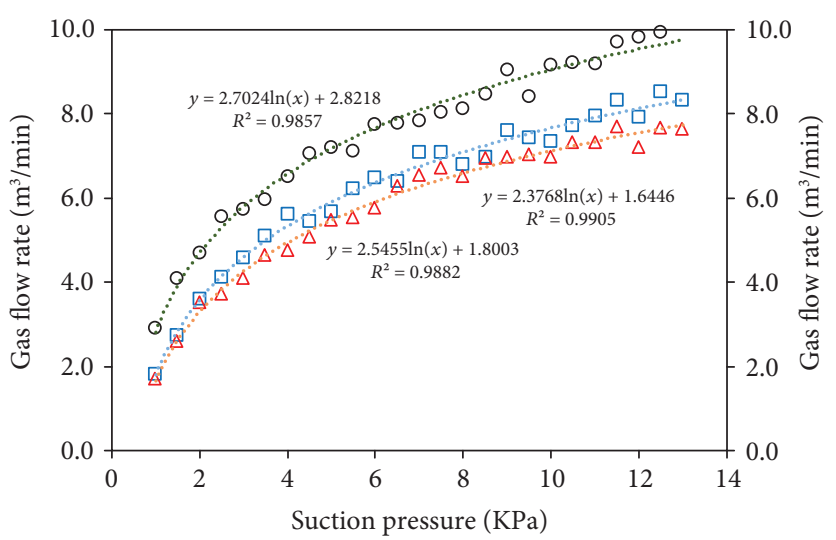

$\square$ Borehole 2

$\triangle$ Borehole 3

$\circ$ Borehole 1

Figure 3: Relations between the gas flow rate from a borehole versus suction pressure in the elastic deformation area and the plastic deformation area. (a) Elastic deformation area. (b) Plastic deformation area.

The field test results showed that the gas flow rates from boreholes in different areas had different sensitivities to the suction pressure; the gas flow rate from boreholes in the elastic deformation area was not sensitive to the suction pressure, whereas that in the plastic deformation area was very sensitive to the suction pressure. Therefore, in order to reduce the pipeline friction resistance and raise the borehole suction pressure in the plastic deformation area, the boreholes with low-concentration gas should be sealed again at the right time. Nevertheless, for a specific mine, the critical gas concentration for secondary borehole sealing is unclear.
According to the Fanning equation, the friction resistance $R$ (in pascals) of gas flow in a round pipe under a laminar flow state is given as

$$
R=\frac{32 s \mu u}{d^{2}}
$$

where $s$ is the pipeline length in meters, $\mu$ is the dynamic viscosity of the gas in $\mathrm{Pa} \cdot \mathrm{s}, u$ is the gas flow speed in $\mathrm{m} / \mathrm{s}$, and $d$ is the pipeline diameter in meters. 
The pipeline friction resistance $R_{i}$ (in pascals) caused by the convergence of gas from the $i$ th group of boreholes into the main pipeline in the elastic deformation area can be acquired through (1) and can be expressed as follows:

$$
R_{i}=\frac{32 s_{i} \mu k_{1 i} \exp \left(k_{2 i} t_{i}\right)}{15 \pi d^{4}}
$$

where $k_{1 i}$ and $k_{2 i}$ are fitting coefficients and $t_{i}$ is the time in days.

The suction pressure $P_{c}$ (in pascals) in grouped boreholes in the plastic deformation area can be expressed as follows:

$$
P_{c}=P-\frac{32 \mu}{15 \pi d^{4}} \sum_{i=1}^{n} s_{i} k_{1 i} \exp \left(k_{2 i} t_{i}\right)
$$

where $P$ is the suction pressure (in pascals) in the main pipeline on the mining-stop-line side.

It was assumed that the gas concentration from the $i$ th group of boreholes in the elastic deformation area declined to $c_{i}$, so that the inleakage fresh air flow rate from this group of boreholes can be expressed as follows:

$$
q_{a}=\frac{k_{1 i} \exp \left(k_{2 i} t_{i}\right)\left(1-c_{i}\right)}{c_{i}} .
$$

The suction pressure loss $R_{i}^{\prime}$ (in pascals) in a borehole in the plastic deformation area caused by air leakage through the $i$ th group of boreholes in the elastic deformation area can be obtained by substituting (6) into (4):

$$
R_{i}^{\prime}=\frac{32 \mu_{a} s_{i} k_{1 i} \exp \left(k_{2 i} t_{i}\right)\left(1-c_{i}\right)}{15 \pi d^{4} c_{i}},
$$

where $\mu_{a}$ is the dynamic viscosity of air in $\mathrm{Pa} \cdot \mathrm{s}$.

According to the relationship between the gas flow rate from boreholes in the plastic deformation area and the suction pressure, the decrease in gas flow rate $Q_{\Delta}$ (in $\mathrm{m}^{3} / \mathrm{min}$ ) in the plastic deformation area caused by air leakage through the $i$ th group of boreholes in the elastic deformation area can be expressed as follows:

$$
Q_{\Delta}=k_{5} \ln \left(\frac{P-32 \mu / 15 \pi d^{4} \sum_{i=1}^{n} s_{i} k_{1 i} \exp \left(k_{2 i} t_{i}\right)}{P-32 \mu / 15 \pi d^{4} \sum_{i=1}^{n} s_{i} k_{1 i} \exp \left(k_{2 i} t_{i}\right)-32 \mu_{a} s_{i} k_{1 i} \exp \left(k_{2 i} t_{i}\right)\left(1-c_{i}\right) / 15 \pi d^{4} c_{i}}\right) .
$$

If $q_{t i}>Q_{\Delta}$, then it was necessary to maintain drainage from this group of boreholes, because the existence of this group of boreholes has a positive effect on the increase in total gas flow rate at the mining seam.

If $q_{t i}<Q_{\Delta}$, then this group of boreholes should be sealed again to raise the suction pressure in the plastic deformation area, increasing the gas flow rate in the plastic deformation area.

2.2. Example Verification and Application. To verify the reliability of the opportunity election model for secondary borehole sealing, the 3710 working face in the Kaiyuan Coal Mine was used as an example for calculation in this study. Gas drainage at the mining seam was conducted from 326 boreholes in 53 groups in the intake airway for the 3710 working face in the Kaiyuan Coal Mine on October 29, and the total gas flow rate in the main pipeline in the intake airway was $3.6 \mathrm{~m}^{3} / \mathrm{min}$ on that day.

The values assigned to coefficients in the negative exponential function and logarithmic function of the model can be obtained according to the fitting results of field test data of the gas flow rate from boreholes in various areas at the 3710 working face. The values assigned to all fluid properties of the gas were obtained under normal temperature and normal pressure. The model parameters are listed in Table 1.

The suction pressure loss caused by inleakage of fresh air in the pipeline in the intake airway for the 3710 working face on October 29 can be calculated by substituting the model parameter values in Table 1 into (7), and then the attenuation curve of the suction pressure in the intake airway for the 3710 working face can be calculated. The comparison curves between field test results and model-calculated results are shown in Figure 4. It can be seen from the test results that the suction pressure in the 1st group of boreholes near the mining stop line was $4 \mathrm{kPa}$, the suction pressure in the boreholes attenuated constantly with the extension of the pipeline, and the suction pressure in the 52nd group of boreholes declined to $2.8 \mathrm{kPa}$, which was $30 \%$ lower than the suction pressure in the 1st group of boreholes. The test results basically agree with the model-calculated results.

The variation of the suction pressure loss caused by inleakage of fresh air in the 52nd group of boreholes and the gas flow rate in the plastic deformation area under different concentrations can be calculated with (5) and (2), as shown in Figure 5. As can be discerned from Figure 5, with the decrease in gas concentration, the suction pressure loss caused by the 52nd group of boreholes increased gradually; in particular, the suction pressure loss increased sharply at the low-concentration stage, which significantly influenced the gas flow rate in the plastic deformation area.

The gas flow loss caused by air leakage through the 52nd group of boreholes can be calculated with (8), as shown in Figure 6. As can be discerned from Figure 6, when the gas concentration in the 52nd group of boreholes was $<15 \%$, the gas flow loss in the plastic deformation area caused by air leakage through this group of boreholes was more than the gas flow rate from this group of boreholes; at this moment, this group of boreholes should be sealed again to 
TABLE 1: Model parameters.

\begin{tabular}{|c|c|c|c|c|c|c|c|}
\hline Parameter & Parameter value & Parameter & Parameter value & Parameter & Parameter value & Parameter & Parameter value \\
\hline$t$ (days) & 180.000 & $\mu_{a}(\mathrm{~Pa} \cdot \mathrm{s})$ & $1.84 \times 10^{-5}$ & $k_{126}$ & 0.241 & $k_{226}$ & -0.020 \\
\hline$L(\mathrm{~m})$ & 1190 & $d(\mathrm{~m})$ & 0.180 & $k_{127}$ & 0.497 & $k_{227}$ & -0.031 \\
\hline$\mu(\mathrm{Pa} \cdot \mathrm{s})$ & $1.11 \times 10^{-5}$ & $P(\mathrm{~Pa})$ & 4000 & $k_{128}$ & 0.267 & $k_{228}$ & -0.017 \\
\hline$k_{11}$ & 0.360 & $k_{21}$ & -0.007 & $k_{129}$ & 0.151 & $k_{229}$ & -0.020 \\
\hline$k_{12}$ & 0.346 & $k_{22}$ & -0.015 & $k_{130}$ & 0.420 & $k_{230}$ & -0.025 \\
\hline$k_{13}$ & 0.176 & $k_{23}$ & -0.012 & $k_{131}$ & 0.321 & $k_{231}$ & -0.012 \\
\hline$k_{14}$ & 0.228 & $k_{24}$ & -0.124 & $k_{132}$ & 0.175 & $k_{232}$ & -0.008 \\
\hline$k_{15}$ & 0.326 & $k_{25}$ & -0.077 & $k_{133}$ & 0.149 & $k_{233}$ & -0.017 \\
\hline$k_{16}$ & 0.150 & $k_{26}$ & -0.007 & $k_{134}$ & 0.324 & $k_{234}$ & -0.031 \\
\hline$k_{17}$ & 0.245 & $k_{27}$ & -0.014 & $k_{135}$ & 0.318 & $k_{235}$ & -0.011 \\
\hline$k_{18}$ & 0.140 & $k_{28}$ & -0.015 & $k_{136}$ & 0.091 & $k_{236}$ & -0.00049 \\
\hline$k_{19}$ & 0.369 & $k_{29}$ & -0.029 & $k_{137}$ & 0.370 & $k_{237}$ & -0.012 \\
\hline$k_{110}$ & 0.382 & $k_{210}$ & -0.052 & $k_{138}$ & 0.185 & $k_{238}$ & -0.082 \\
\hline$k_{111}$ & 0.242 & $k_{211}$ & 0.000 & $k_{139}$ & 0.396 & $k_{239}$ & -0.225 \\
\hline$k_{112}$ & 0.140 & $k_{212}$ & -0.062 & $k_{140}$ & 0.108 & $k_{240}$ & -0.030 \\
\hline$k_{113}$ & 0.503 & $k_{213}$ & -0.028 & $k_{141}$ & 0.108 & $k_{241}$ & -0.006 \\
\hline$k_{114}$ & 0.129 & $k_{214}$ & -0.006 & $k_{142}$ & 0.470 & $k_{242}$ & -0.107 \\
\hline$k_{115}$ & 0.213 & $k_{215}$ & -0.089 & $k_{143}$ & 0.140 & $k_{243}$ & -0.005 \\
\hline$k_{116}$ & 0.129 & $k_{216}$ & -0.007 & $k_{144}$ & 0.525 & $k_{244}$ & -0.026 \\
\hline$k_{117}$ & 0.182 & $k_{217}$ & -0.011 & $k_{145}$ & 0.081 & $k_{245}$ & -0.211 \\
\hline$k_{118}$ & 0.154 & $k_{218}$ & -0.008 & $k_{146}$ & 0.182 & $k_{246}$ & -0.122 \\
\hline$k_{119}$ & 0.279 & $k_{219}$ & -0.037 & $k_{147}$ & 0.275 & $k_{247}$ & -0.053 \\
\hline$k_{120}$ & 0.393 & $k_{220}$ & -0.022 & $k_{148}$ & 0.411 & $k_{248}$ & -0.109 \\
\hline$k_{121}$ & 0.131 & $k_{221}$ & -0.009 & $k_{149}$ & 0.394 & $k_{249}$ & -0.038 \\
\hline$k_{122}$ & 0.398 & $k_{222}$ & -0.090 & $k_{150}$ & 0.222 & $k_{250}$ & -0.075 \\
\hline$k_{123}$ & 0.267 & $k_{223}$ & -0.017 & $k_{151}$ & 0.314 & $k_{251}$ & -0.011 \\
\hline$k_{124}$ & 0.189 & $k_{224}$ & -0.165 & $k_{152}$ & 0.354 & $k_{252}$ & -0.063 \\
\hline$k_{125}$ & 0.065 & $k_{225}$ & -0.010 & $k_{3}$ & 2.4 & $k_{4}$ & -14.8 \\
\hline
\end{tabular}

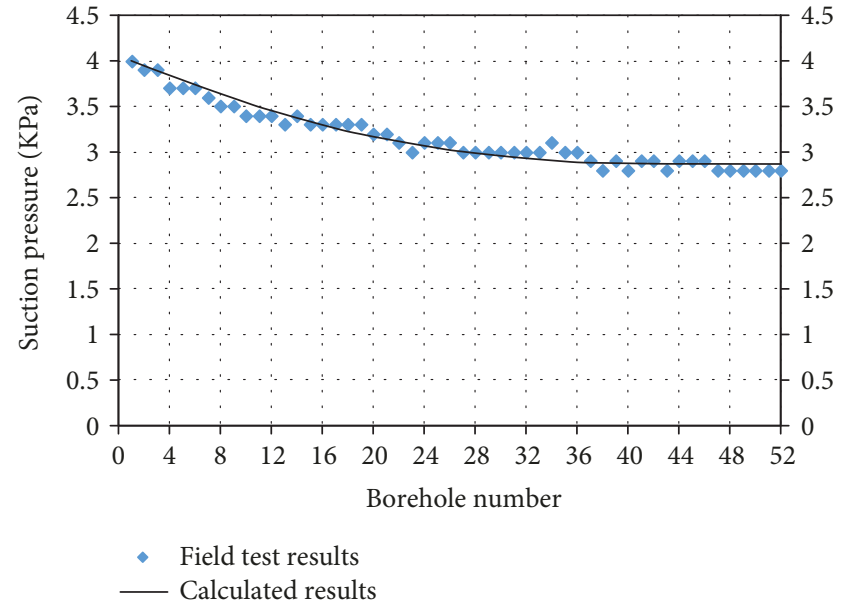

Figure 4: Comparison between field test results and modelcalculated results. raise the gas concentration in the pipeline at the mining seam, with the total gas flow rate being guaranteed.

\section{Experimental Study on Dynamic Secondary Borehole Sealing}

3.1. Secondary Borehole Sealing Experimental Device. Under the influence of the advanced abutment pressure, the tightness of the borehole is destroyed, so secondary borehole sealing is needed. However, current borehole-sealing devices do not have a secondary borehole-sealing functionality. To solve the above problems, a secondary borehole-sealing experimental device (Figure 7) was developed. This experimental device uses an iron pipe to simulate the drainage borehole. With a length of $6 \mathrm{~m}$ and an inside diameter of $120 \mathrm{~mm}$, the iron pipe was divided into upper and lower halves along the central axis and spliced with rectangular flanges and sealing gaskets (Figures $7(\mathrm{a})$ and $7(\mathrm{c})$ ). At the time of the primary borehole sealing, the slurry fills the bag 


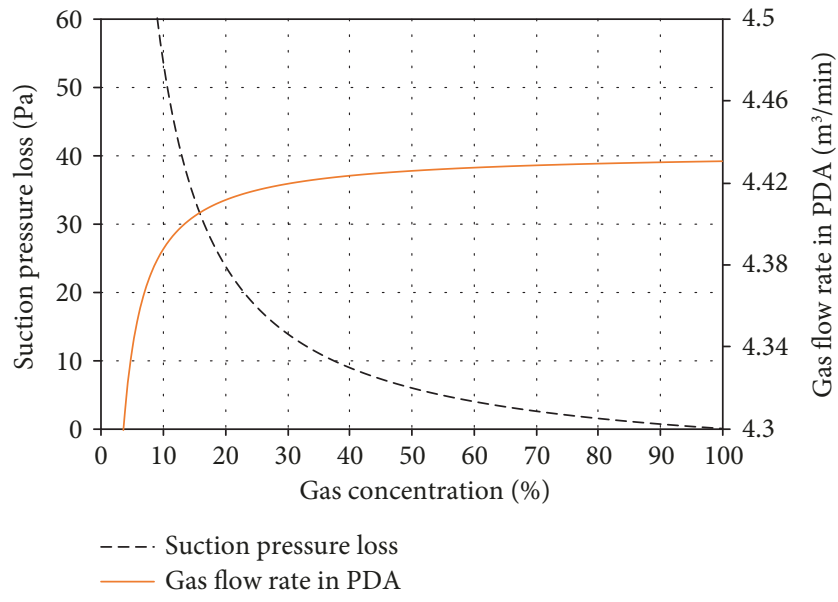

FIGURE 5: Curves of suction pressure loss caused by air leakage through the 52nd group of boreholes and the gas flow rate in the plastic deformation area (PDA) under different concentrations.

in the inner section and the bag in the middle section first. When the design pressure is reached, the explosion valve is opened and the slurry fills the space between the two bags. At the time of the secondary borehole sealing, the slurry fills the outer bag close to the orifice. When the design pressure is reached, the explosion valve is opened and the slurry fills the outer sealing section. After filling the space outside the borehole-sealing pipe, the slurry enters the additional devices outside the iron pipe (Figures 7(b) and 7(d)). The flow conditions of the slurry can be observed through these additional devices. During the secondary borehole-sealing experiment, the developed borehole-sealing device worked accurately, providing secondary borehole-sealing functionality to guarantee repair of the failed borehole in the advanced abutment pressure loading stage.

3.2. Borehole-Sealing Material. In the last few decades, some sealing materials have been developed. Zhai et al. developed a flexible paste sealing material [7]. Sun et al. studied the influence of sodium hydroxide content in borehole-sealing materials on the setting time and concluded that sodium hydroxide can accelerate the crystallization of cement-type borehole-sealing materials [8]. Ren et al. made cement-type borehole-sealing materials that allowed simple operation at low cost [9]. Stryczek et al. studied the rheological parameters of fresh sealing slurries and ways of improving their liquidity by using a properly selected third-generation superplasticizer [10]. Pusch described a technique to delay hydration and maturation of borehole seals of clay [11]. Van Geet et al. studied the feasibility of sealing off a borehole in plastic Boom clay by means of precompacted bentonite blocks [12]. Akgun and Daemen studied the influence of elevated temperature and degree of saturation on the boreholesealing performance of a cement grout and found that the axial strength decreases with increasing curing and testing temperature $[13,14]$. However, dry shrinkage will occur for sealing materials in the setting process, resulting in a continuous decline in borehole tightness. In order to solve the above problem, a high-water-expansion material was developed
[15]. The high-water-expansion slurry has a certain degree of expandability after the final setting, overcoming the dry shrinkage effect of the other borehole-sealing materials.

The high-water-expansion material is made by adding material C (an expansion agent) into the high-water material as an auxiliary material. The addition of material $\mathrm{C}$ enables the high-water material slurry to expand during the curing process, which enhances the sealing performance of the slurry on the fractures of coal rock masses around the gas drainage borehole. The hydrated product of the high-waterexpansion material is mainly ettringite, and its molecular formula is $\left(\mathrm{Ca}_{6} \mathrm{Al}_{2}(\mathrm{OH})_{12} \cdot 24 \mathrm{H}_{2} \mathrm{O}\right) \cdot\left(\mathrm{SO}_{4}\right)_{3} \cdot 2 \mathrm{H}_{2} \mathrm{O}$. Ettringite exhibits strong crystallization when it is dissolved in water. After crystallization, it forms needle-like crystals, which are interwoven into a network structure, as shown in Figure 8. Studies have shown that the ettringite crystals can retain water equivalent to $75 \%$ of their own mass even if they are fully compressed under stress [16].

\subsection{In Situ Experiment}

3.3.1. Overview of Experimental Working Face. To investigate the effects of applying different borehole-sealing materials and borehole-sealing techniques, a comparative test of the borehole-sealing effects of high-water-expansion materials, cement mortar, and polyurethane and a dynamic secondary borehole-sealing test were conducted in the return airway of working face 3908 of the Kaiyuan Coal Mine. The average thickness of the coal seam at working face 3908 is $2.34 \mathrm{~m}$. The working face elevation is $702-749 \mathrm{~m}$, and the ground elevation is $1109-1172 \mathrm{~m}$. The strike length is $\sim 1469 \mathrm{~m}$, the inclination length is $220 \mathrm{~m}$, and the area is $323,180 \mathrm{~m}^{2}$. The dip angle of the coal seam averages $4^{\circ}$, the horizontal length of the boreholes in the coal seam is $120 \mathrm{~m}$, and the borehole diameter is $120 \mathrm{~mm}$.

3.3.2. Experimental Scheme. To compare the effects of different borehole-sealing materials, an observation station was set up at a distance of $100 \mathrm{~m}$ from the cutting hole of working face 3908, and six boreholes along the coal seam were drilled in the observation station: boreholes HW-1 and HW-2 were sealed with the high-water-expansion slurry, boreholes CM-1 and CM-2 were sealed with cement mortar, and boreholes PU-1 and PU-2 were sealed with polyurethane, as shown in Figure 9.

To investigate the secondary borehole-sealing effect, secondary borehole sealing was performed on boreholes HW-1 and HW-2 when their tightness was destroyed by the advanced abutment pressure (sealing length of $8 \mathrm{~m}$ ), but no secondary borehole sealing was performed on boreholes CM-1, CM-2, PU-1, and PU-2. The comparative test scheme for different borehole-sealing materials and techniques is shown in Figure 10.

3.3.3. Analysis of Experimental Results. Borehole sealing was performed immediately after the construction of boreholes, and then the valve on the borehole pipeline was closed. As the amount of gas emission from the borehole increases, positive pressure begins to build up inside the borehole. To investigate the air tightness of the test borehole, the internal 


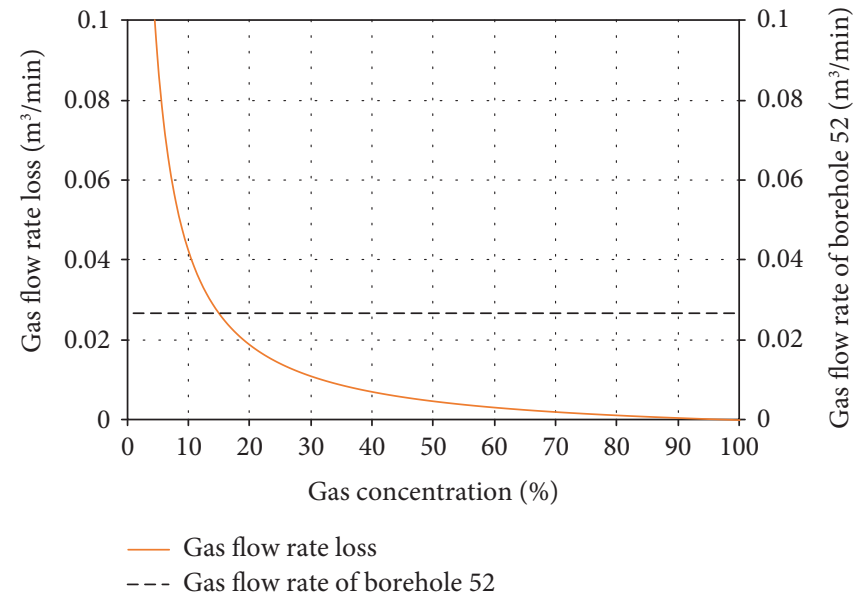

Figure 6: Curves of gas flow loss caused by air leakage through the 52nd group of boreholes under different concentrations.

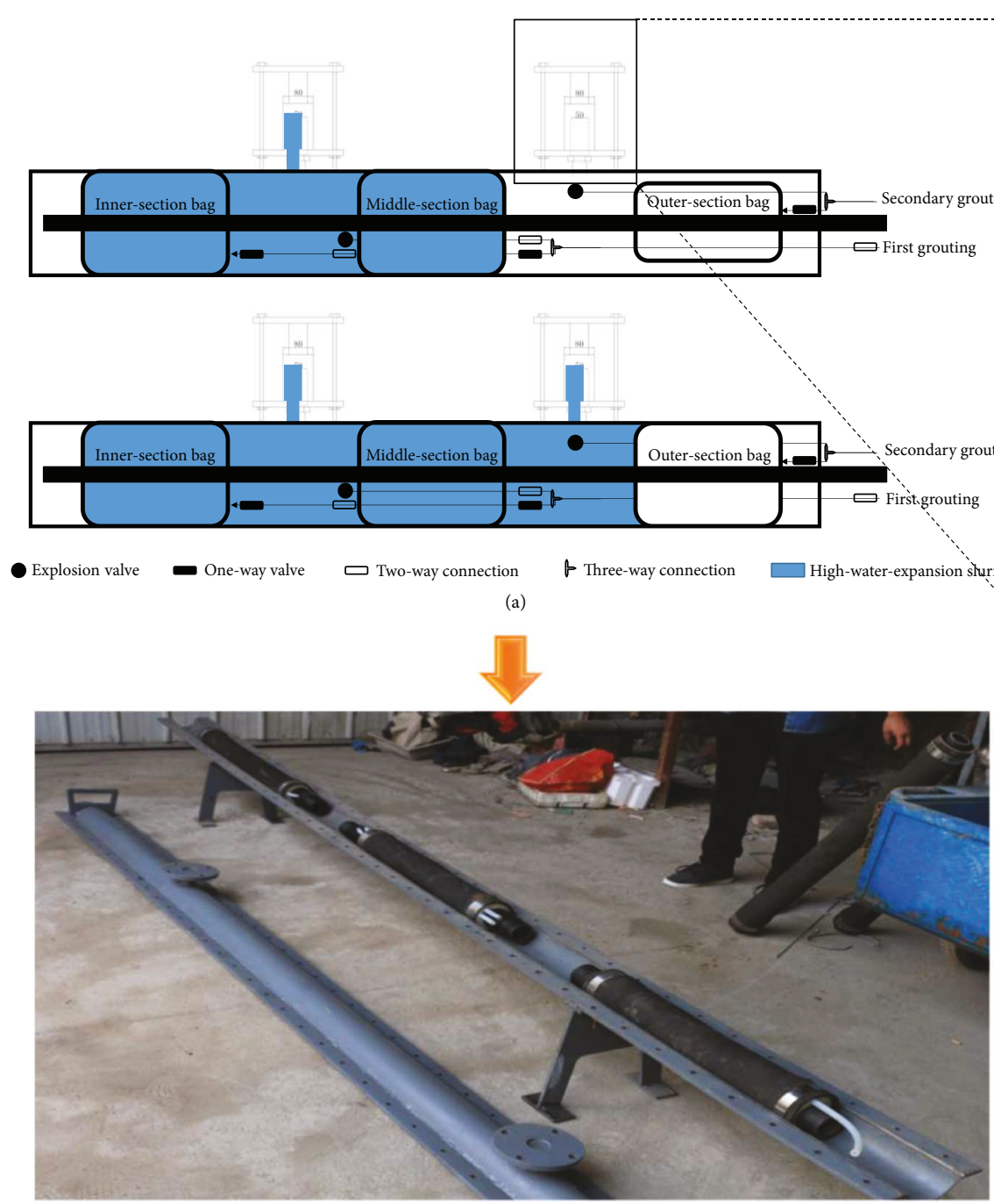

(c)
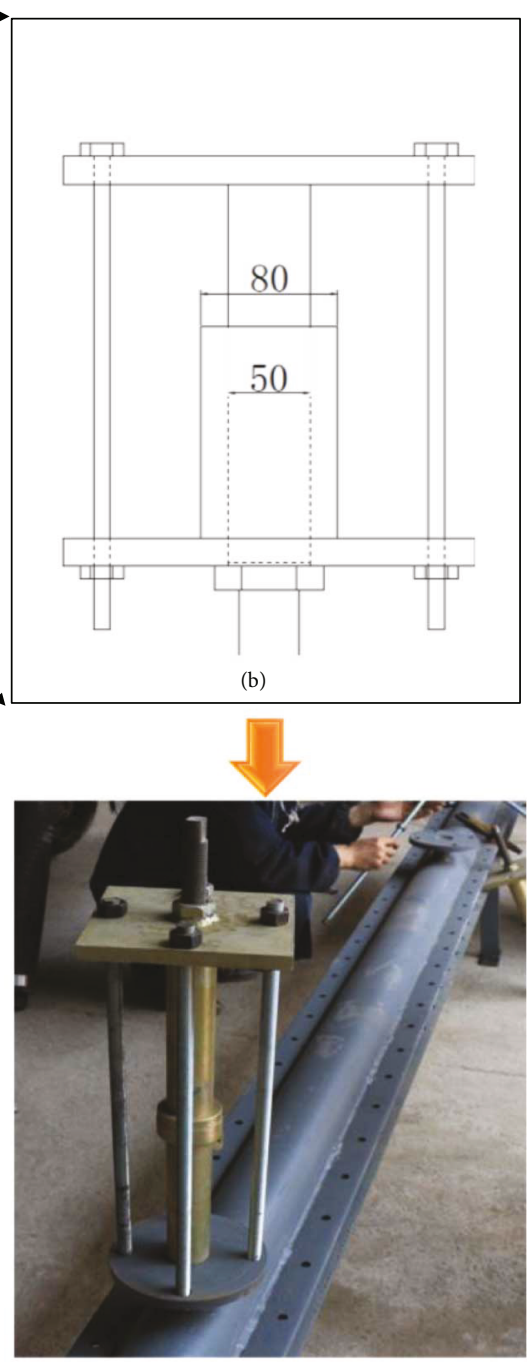

(d)

Figure 7: Schematic and photographs of the experimental device. (a, c) Secondary borehole sealing device. (b, d) Additional devices. 

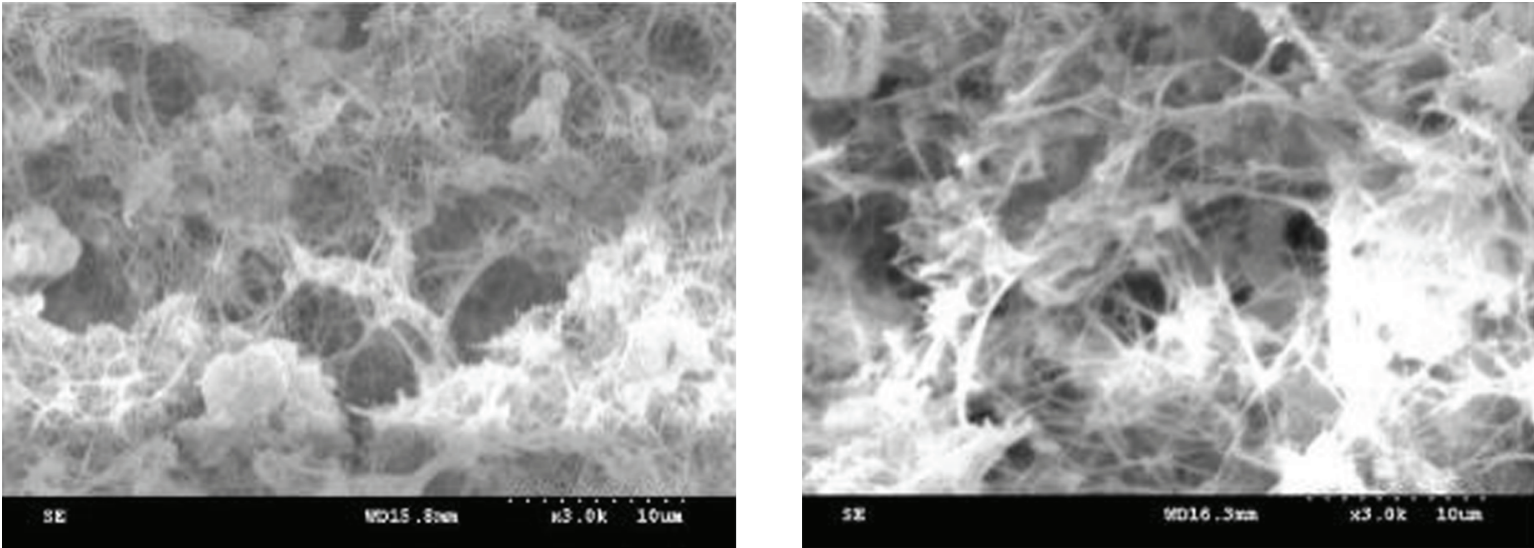

FIGURE 8: Network structure of ettringite crystals.

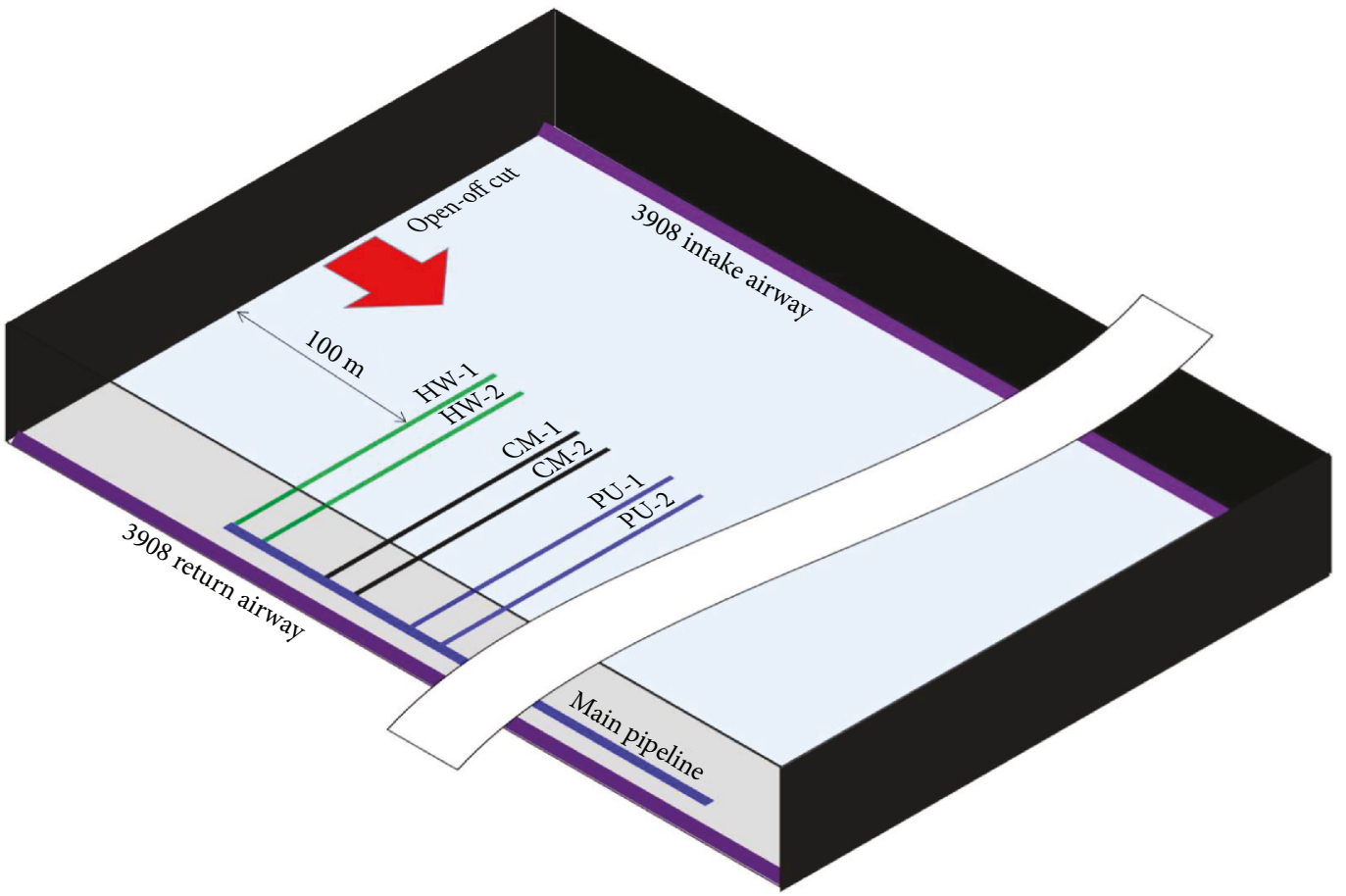

FIgURE 9: Borehole layout in the observation station.

pressure in the borehole was observed through a nozzle on the pipeline, and the observational results are shown in Figure 11(a). As can be seen from Figure 11(a), the positive pressures in boreholes $\mathrm{HW}-1$ and $\mathrm{HW}-2$ are obviously higher than those in boreholes CM-1, CM-2, PU-1, and PU-2. The average positive pressures in boreholes $\mathrm{HW}-1$ and $\mathrm{HW}-2$ are 139.5 and $116 \mathrm{mmHg}$, respectively, while those in boreholes CM-1, CM-2, PU-1, and PU-2 are 31, $62.3,2.3$, and $1.0 \mathrm{mmHg}$, respectively. The positive pressure in the borehole sealed with the high-water-expansion material was a factor of 100 greater than that in the borehole sealed with polyurethane. Therefore, it can be seen that the highwater-expansion material can better seal the gap between the drainage pipeline and the borehole wall. The high-waterexpansion slurry has a certain degree of expandability after the final setting, overcoming the dry shrinkage defects after the setting of the cement mortar and better sealing the gap around the borehole.

With the advance of the working face, the station continuously approaches the working face. During this process, the suction pressure, gas concentration, and gas drainage amount in the test borehole were continuously observed. The observational results are shown in Figures 11(b)-11(d). After drainage under negative pressure, the suction pressures and gas concentrations in boreholes $\mathrm{HW}-1$ and $\mathrm{HW}-2$ are obviously higher than those in boreholes CM-1, CM-2, PU-1, and PU-2, which fully demonstrates that the tightness of the borehole sealed with the high-water-expansion slurry is relatively good. However, because of the influence of the advanced abutment pressure, the airtightness of test boreholes became 


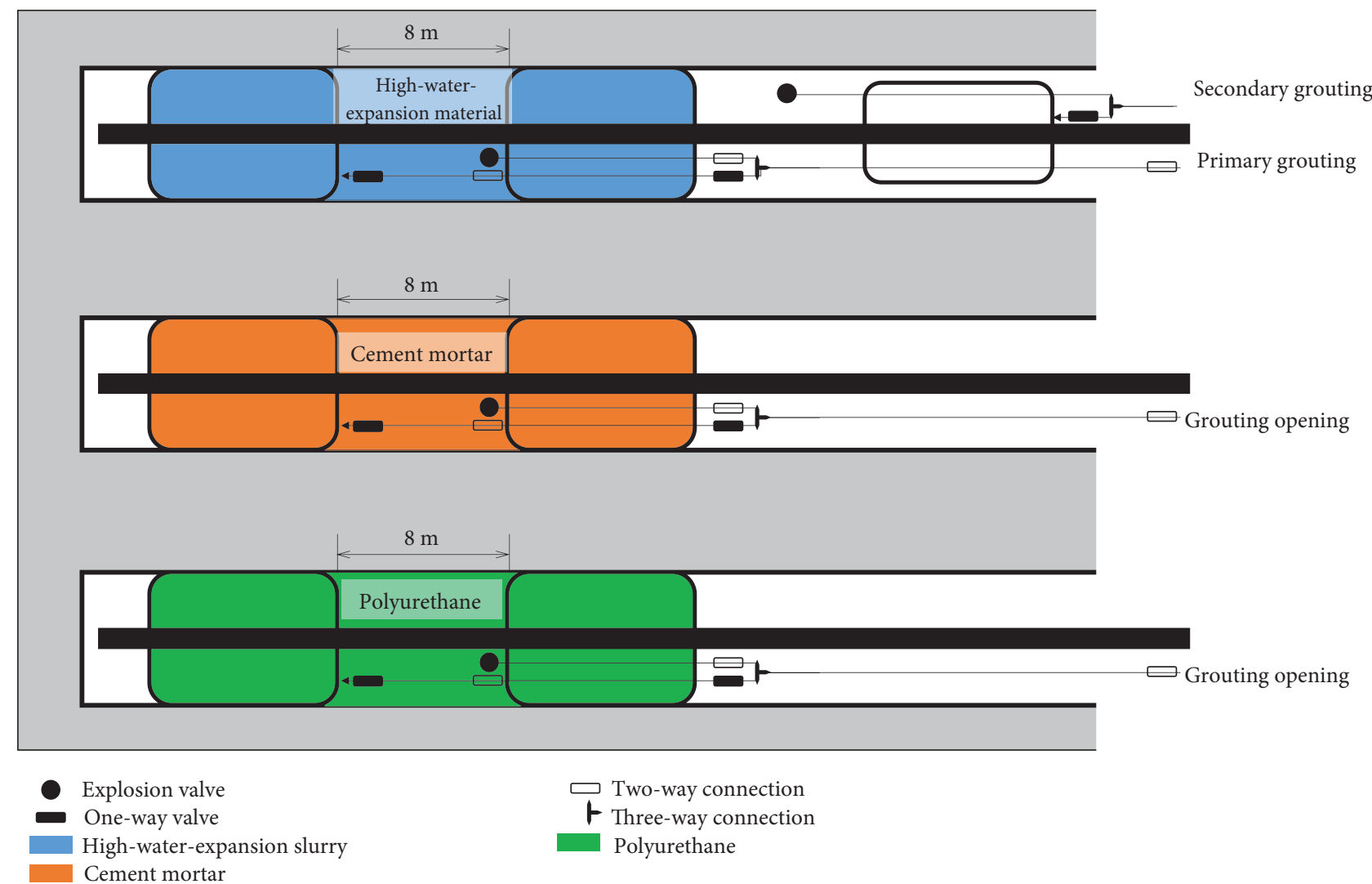

FIGURE 10: Comparative test scheme for different borehole-sealing materials and techniques.

damaged to different extents, resulting in a decrease in the suction pressure and the gas concentration in test boreholes, but the decrease in the suction pressure and the gas concentration in test boreholes sealed with the high-water-expansion slurry were relatively small (Figures 11(b) and 11(c)).

When the test hole was $32 \mathrm{~m}$ away from the working face, the gas concentration in the test boreholes decreased suddenly because of the peak of the working face advanced abutment pressure, which indicates that the tightness of the test borehole was destroyed (Figure 11(c)). The gas concentration in boreholes HW-1 and HW-2 were $<15 \%$, and the gas concentration is lower than the critical gas concentration for secondary borehole-sealing. Therefore, secondary borehole sealing was performed on boreholes HW-1 and HW-2 at this time, and the suction pressures and gas concentrations in boreholes HW-1 and HW-2 increased significantly after secondary borehole sealing. The suction pressure in borehole $\mathrm{HW}-1$ increased from 7.6 to $11.3 \mathrm{kPa}$, and the suction pressure in borehole HW-2 increased from 8.5 to $13.2 \mathrm{kPa}$ (Figure 11(b)). The gas concentration in borehole HW-1 increased from $14 \%$ to $92 \%$, and the gas concentration in borehole HW-2 increased from $13 \%$ to $65 \%$ (Figure 11(c)).

As the working face continued to advance, the test borehole entered the advanced abutment pressure loading stage, the permeability of the coal rock masses around the borehole increased, and the gas drainage amount began to increase continuously (Figure 11(d)). The higher suction pressure increases the amount of gas extracted from boreholes
HW-1 and HW-2 compared to that from the other boreholes (CM-1, CM-2, PU-1, and PU-2). The average drainage amount for boreholes HW-1 and HW-2 in the advanced abutment pressure loading stage reached $1.3 \mathrm{~m}^{3} / \mathrm{min}$, a factor of 3.61 higher than that $\left(0.36 \mathrm{~m}^{3} / \mathrm{min}\right)$ of comparison boreholes in the advanced abutment pressure loading stage.

In conclusion, owing to the good fluidity of the highwater-expansion slurry and the high strength of the consolidated body after setting, the tightness of the boreholes sealed with the high-water-expansion slurry is obviously superior to that of boreholes sealed with cement mortar and polyurethane. When a borehole is destroyed by the peak of the advanced abutment pressure, secondary borehole sealing can significantly improve borehole suction pressure, gas concentration, and gas drainage amount in the advanced abutment pressure loading stage and can fully utilize the pressure relief and increased permeability of coal masses in front of the working face to improve gas drainage from the coal seam.

\section{Conclusions}

(1) In this paper, a field test was conducted to determine how suction pressure affected gas drainage at the mining seam, and the test results showed that the influence of suction pressure on the gas flow rate from boreholes in the elastic deformation area was relatively minor, and the gas flow rate from boreholes 


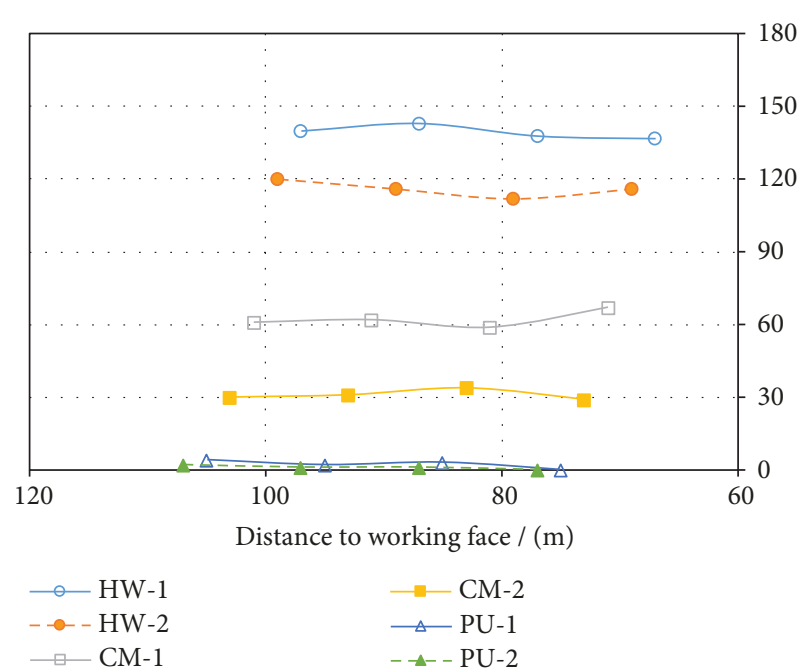

(a)

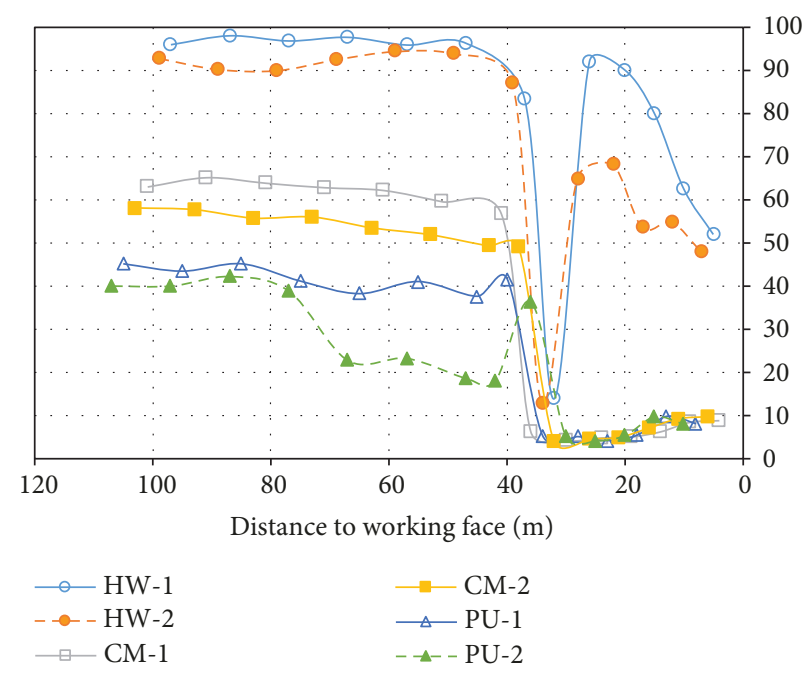

(c)

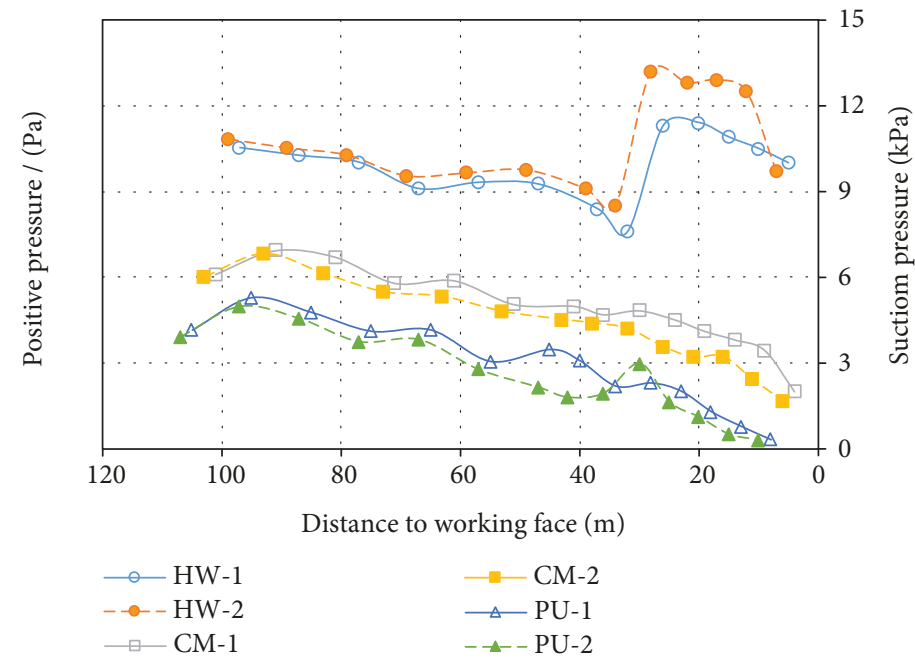

(b)

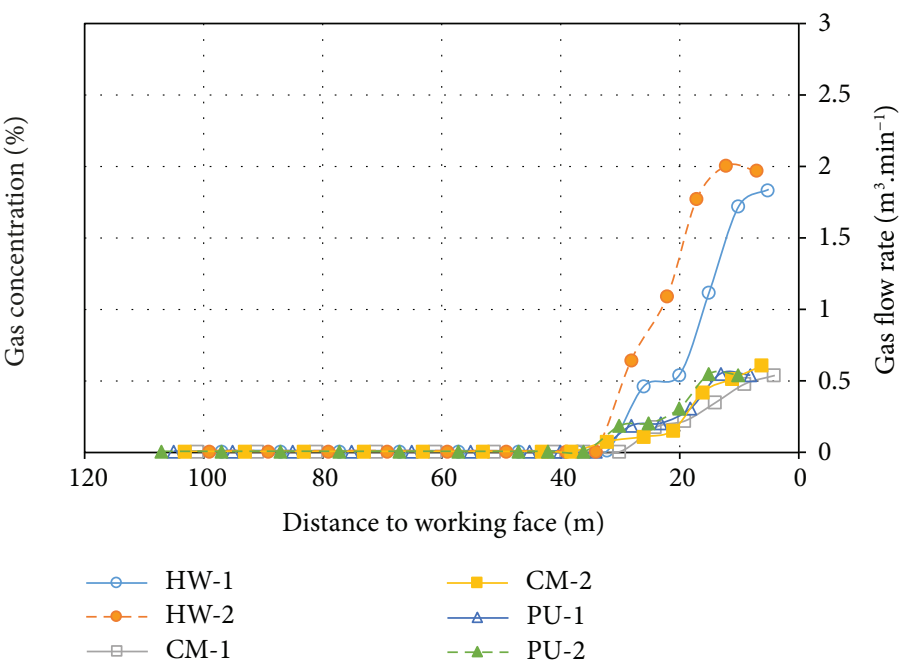

(d)

FIGURE 11: Tightness and gas drainage effect for boreholes under different borehole-sealing materials and borehole-sealing techniques. (a) Positive pressure. (b) Suction pressure. (c) Gas concentration. (d) Gas flow rate.

in the elastic deformation area attenuated constantly with drainage time according to a negative exponential function; the influence of suction pressure on the gas flow rate from boreholes in the plastic deformation area was relatively large, and the gas flow rate from boreholes increased according to a logarithmic function with increasing suction pressure.

(2) An opportunity election model of secondary boreholesealing was established, and the model-calculated results were verified with the test results from the drainage pipeline in the intake airway for the 3710 working face in the Kaiyuan Coal Mine. The test results agreed with the model-calculated results. The critical gas concentration for secondary boreholesealing was obtained through model calculation. A secondary borehole-sealing experimental device was developed. The developed borehole-sealing device worked accurately, providing secondary borehole- sealing functionality to guarantee the repair of the failed borehole in the advanced abutment pressure loading stage.

(3) To compare the application effects of different borehole-sealing materials and borehole-sealing techniques, a comparative test of the boreholesealing effects of high-water-expansion materials, cement mortar, and polyurethane and a dynamic secondary borehole-sealing test were performed in the return airway of working face 3908 of the Kaiyuan Coal Mine. The test results showed that the tightness of the boreholes sealed with high-waterexpansion material is obviously better than that of boreholes sealed with cement mortar and polyurethane. When a borehole is destroyed by the peak of the advanced abutment pressure, secondary borehole sealing can significantly improve borehole suction pressure in the advanced abutment pressure loading 
stage and can fully utilize the pressure relief and permeability increase of the coal mass in front of the working face to improve gas drainage from the coal seam.

\section{Data Availability}

All relevant data are available from FigShare, under the DOI: (https://figshare.com/s/e72c1f8e7c8ed0bcf963).

\section{Conflicts of Interest}

The authors declare that there is no conflict of interest regarding the publication of this paper.

\section{Acknowledgments}

Financial support for this work was provided by the Fundamental Research Funds for the Central Universities (no. 2015XKZD04), and Priority Academic Program Development of Jiangsu Higher Education Institutions (no. SZBF2011-6-B35). The authors thank X. Peng for assistance with the experiments and Y. Dong for valuable discussion.

\section{References}

[1] G. Zhai and W. He, "Conventional natural gas' actual succeeding resources-coalbed methane," Natural Gas Industry, vol. 24 , no. 5, pp. 1-3, 2004.

[2] W. Qin, J. Xu, and G. Hu, "Optimization of abandoned gob methane drainage through well placement selection," Journal of Natural Gas Science and Engineering, vol. 25, pp. 148-158, 2015.

[3] G. Hu, H. Wang, H. Tan, X. Fan, and Z. Yuan, "Gas seepage equation of deep mined coal seams and its application," Journal of China University of Mining and Technology, vol. 18, no. 4, pp. 483-487, 2008.

[4] G. Hu, J. Xu, H. Wang, Z.-y. Jin, and R. Wu, "Research on a dynamically coupled deformation and gas flow model applied to low-permeability coal," Journal of China University of Mining \& Technology, vol. 40, no. 1, pp. 1-6, 2011.

[5] Z. Jiang, Y. Tao, and F. Wang, "Research and application on automatic adjusting control system of concentration of gas extraction," Coal Technology, vol. 33, no. 10, pp. 28-30, 2014.

[6] M. Qian and P. Shi, Mining Pressure and Strata Control, Jiangsu Province, China University of Mining and Technology Press, China, 2003.

[7] C. Zhai, X. Xiang, X. Yu, S. Peng, G. H. Ni, and M. Li, "Sealing performance of flexible gel sealing material of gas drainage borehole," Journal of China University of Mining \& Technology, vol. 42, no. 6, pp. 982-988, 2013.

[8] W. Sun, B. Guo, and R. Zhang, "Effect of sodium hydroxide on properties of new material for sealing gas drainage boreholes," China Safety Science Journal, vol. 26, no. 3, pp. 98-102, 2016.

[9] Q. Ren, J. Zou, and L. Zhao, "A simple detection method for gas drainage hole sealing quality and its field test," Mining Safety \& Environmental Protection, vol. 42, no. 1, pp. 89-91, 2016.

[10] S. Stryczek, A. Gonet, R. Wiśniowski, and A. Złotkowski, "New-generation sealing slurries for borehole injection purposes," Archives of Mining Sciences, vol. 60, no. 4, 2015.
[11] R. Pusch, "A technique to delay hydration and maturation of borehole seals of expansive clay," Engineering Geology, vol. 121, no. 1-2, pp. 1-6, 2011.

[12] M. Van Geet, G. Volckaert, W. Bastiaens et al., "Efficiency of a borehole seal by means of pre-compacted bentonite blocks," Physics and Chemistry of the Earth, vol. 32, no. 1-7, pp. 123134, 2007.

[13] H. Akgün and J. J. K. Daemen, "Influence of elevated temperature on axially loaded expansive cement grout borehole plug sealing performance," Magazine of Concrete Research, vol. 52, no. 5, pp. 379-394, 2000.

[14] H. Akgun and J. J. K. Daemen, "Influence of degree of saturation on the borehole sealing performance of an expansive cement grout," Cement and Concrete Research, vol. 30, no. 2, pp. 281-289, 2000.

[15] G. Hu, C. Lan, W. He, and Y. Zhu, "Study on groutability of super high-aqueous expansive slurry during hole sealing process of gas drainage holes," Safety in coal mines, vol. 48, no. 7, pp. 9-11, 2007.

[16] G. Feng, Research on the Superhigh-Water Packing Material and Filling Mining Technology and Their Application, Ph.D. Dissertation, University of Mining and Technology, Xuzhou, China, 2010. 

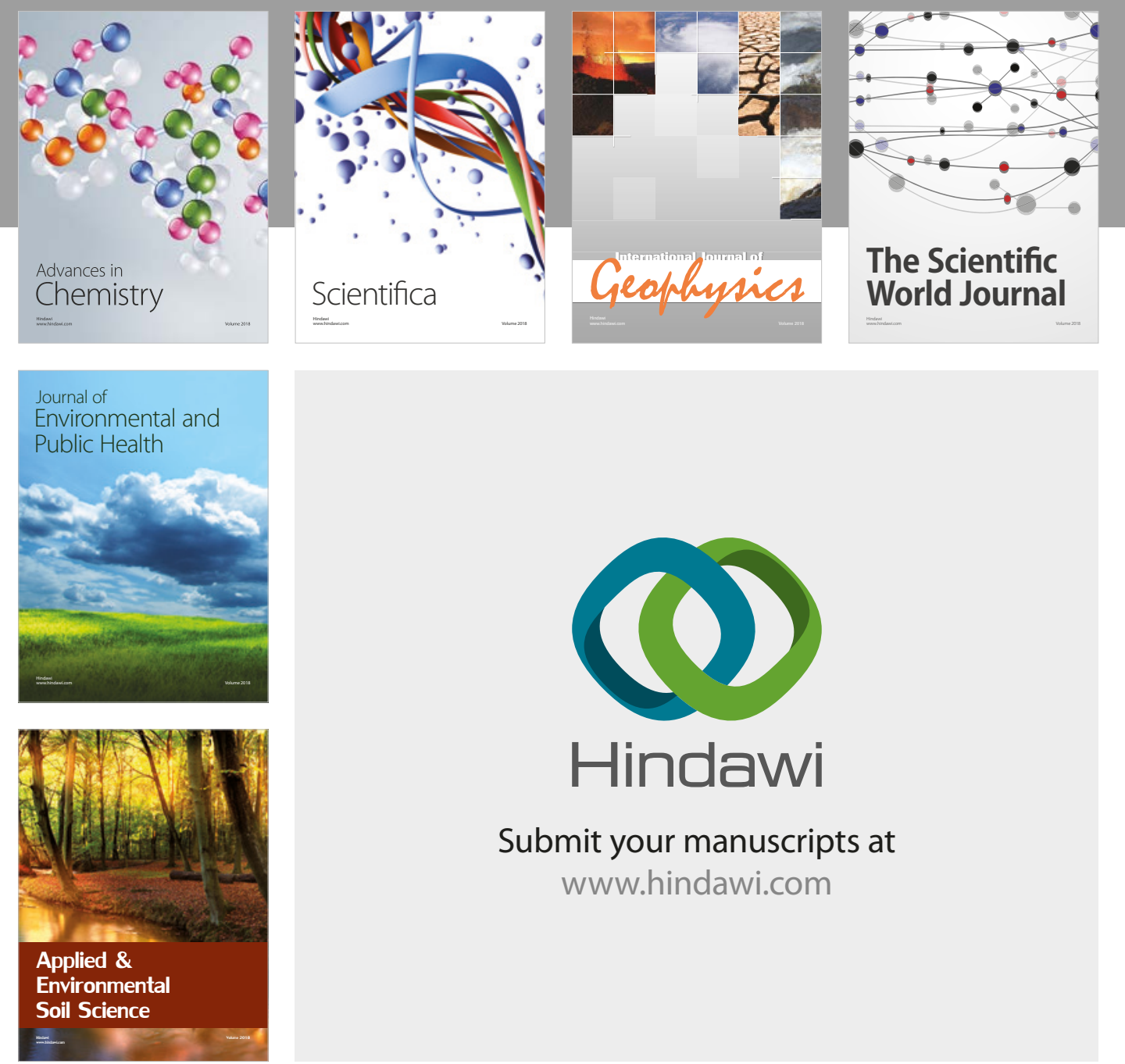

The Scientific

\section{World Journal}
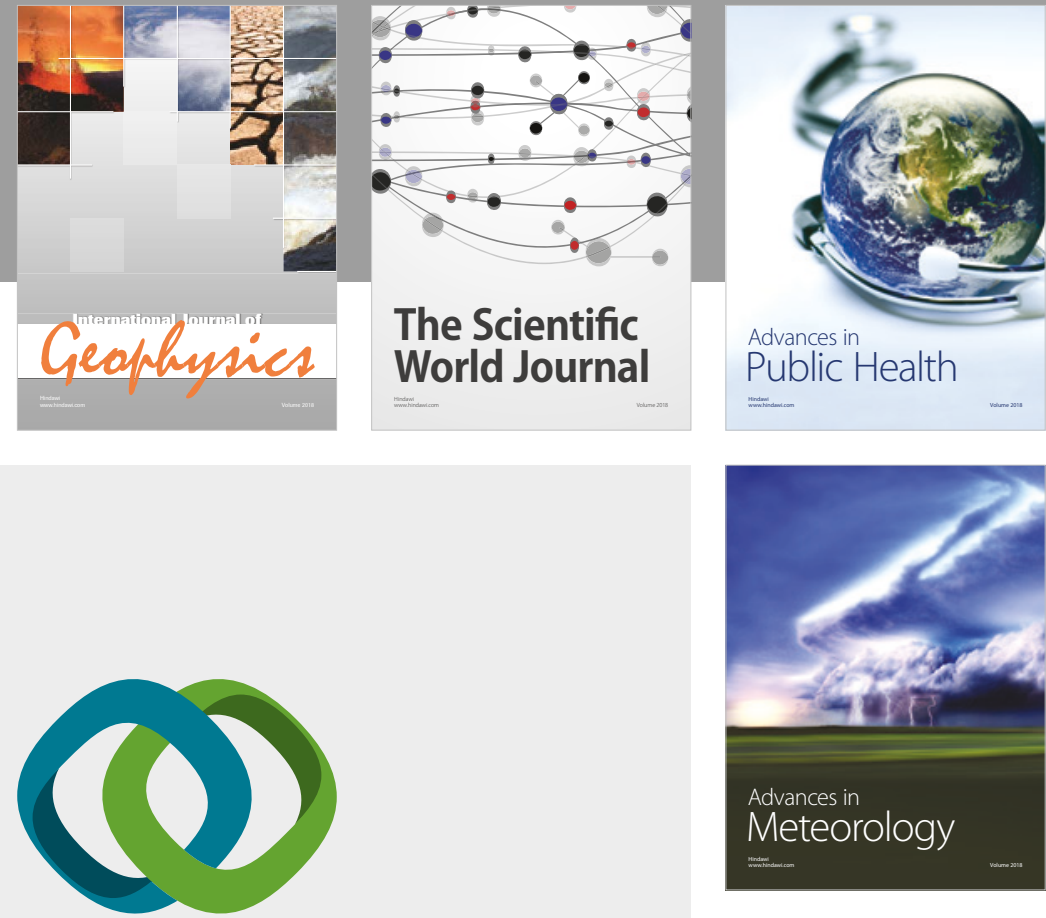

Advan

Public Health

\section{Hindawi}

Submit your manuscripts at

www.hindawi.com
